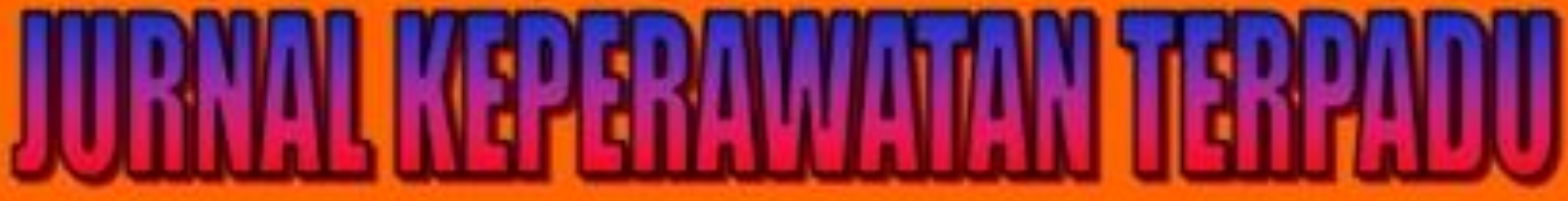

\section{Integrated Nursing Journal}

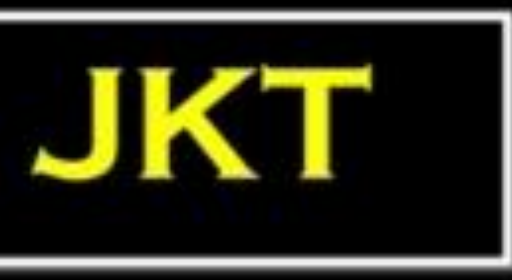

\section{p-ISSN: 2406-9698 (Print) e-ISSN: 2685-0710 (Online)}

\section{Vol. 2 No. 1 April 2020}

\section{KEMENTERIAN KESEHATAN RI}

\section{POLTEKKES MATARAM JURUSAN KEPERAWATAN}

Jalan Kesehatan V/10 Mataram NTB - http://jkt.poltekkes-mataram.ac.id 


\section{Vol. 2 No. 1 April 2020}

\section{Editorial Team}

\section{Editor-in-Chief}

Moh. Arip, Jurusan Keperawatan Poltekkes Kemenkes Mataram, Indonesia

\section{Editorial Board}

1. Mr. Frans Judea Samosir, Universitas Prima Indonesia, Indonesia

2. Baiq Kirana Kitna, Jurusan Keperawatan, Poltekkes Kemenkes Mataram, Indonesia

3. Irwan Budiana, Jurusan Keperawatan, Poltekkes Kemenkes Kupang, Indonesia

4. dr. Baskoro Tri Laksono, RS. Biomedika Mataram, Indonesia

5. Sitti Rusdianah, Jurusan Keperawatan, Poltekkes Kemenkes Mataram, Indonesia

6. Mira Utami Ningsih, Jurusan Keperawatan, Poltekkes Kemenkes Mataram, Indonesia

\section{Alamat Redaksi:}

Jurusan Keperawatan Mataram Poltekkes Kemenkes Mataram Kampus B

Jl. Kesehatan V No.10 Pajang Timur-Mataram NTB-Indonesia, 83127

Telepon: +62 370-621383

Fax: +62 370-631160

Email: jurnalkeperawatanterpadu2019@gmail.com

Laman: http://jkt.poltekkes-mataram.ac.id/index.php/home/index 


\section{Vol. 2, No. 1, April 2020}

\section{DAFTAR ISI}

Pengaruh Self Hypnosis Terhadap Respon Cemas Mahasiswa

Pada Ujian Tahap Akhir Program Di STIKes Buana Husada Ponorogo

Yudha Anggit Jiwantoro, Afifa Ika Kridawati, Danies Tunjung Pratiwi

Efektifitas Tepid Water Sponge Terhadap Penurunan Suhu Tubuh Pada Anak Dengan Masalah Keperawatan Hipertermia: Studi Kasus

Emy Mulyani, Nur Eni Lestari

Perilaku Pencegahan Penyakit Tidak Menular Pada Remaja Ambon

Hamdan Hariawan, Martini Tidore, Greeny Z. Rahakbau

Pengetahuan dan Sikap Perawat Berhubungan dengan Pelaksanaan Patient

Safety

Elisa Sulistia Fitri, Kusnanto, Herdina Maryanti

Efektivitas Art Therapy terhadap Pengetahuan dan Praktik Pemeliharaan Kesehatan Gigi pada Anak Usia Prasekolah

Linda Widyarani, Wiwi Kustio Priliana, Cecilya Kustanti

Konsep Diri Remaja Yang Mengalami Bullying

Puji Lestari, Liyanovitasari

Pengaruh Senam Tai Chi Terhadap Peningkatan Kualitas Tidur Lansia Di Balai Sosial Lanjut Usia Mandalika

Fathaillah Liestanto, Dina Fitriana

Hubungan Komunikasi Terapeutik Perawat Dengan Tingkat Kecemasan

Pasien Hemodialisa Di RSUD Dr Harjono Ponorogo

Ervan Nur Cholis, Rumpiati Rumpiati, Ike Sureni

Upaya Mengatasi Nyeri Post Op Sectio Cesaria Melalui Foot Massage Therapy Diruang Nifas RSUD Kota Mataram

Masadah, Cembun, Ridawati Sulaeman

Peningkatan Pemberdayaan Keluarga Melalui PINKESGA (Paket Informasi Keluarga) Kehamilan Dalam Mengambil Keputusan Merawat Ibu Hamil Mardiatun, Dewi Purnamawati, Ely Mawaddah
Page

$1-6$

Page

$7-14$

Page

$15-21$

Page

22-28

Page

29-39

Page

40-46

Page

$47-53$

Page

54-63

Page

$64-70$

Page

$70-78$ 


\title{
PENGETAHUAN DAN SIKAP PERAWAT BERHUBUNGAN DENGAN PELAKSANAAN PATIENT SAFETY
}

\author{
Elisa Sulistia Fitri ${ }^{1}$, Kusnanto ${ }^{2}$, dan Herdina Maryanti ${ }^{3}$ \\ ${ }^{1,2,3}$ Fakultas Keperawatan, Universitas Airlangga, Indonesia
}

\begin{abstract}
ABSTRAK
Patient safety merupakan suatu variabel untuk mengukur dan mengevaluasi kualitas pelayanan keperawatan yang berdampak terhadap pelayanan kesehatan dan bertujuan menurunkan angka kejadian tidak diharapkan (KTD) selama pasien dalam perawatan. Pelaksanaan patient safety di Puskesmas Bayan hanya sebatas pada pencatatan jumlah pasien yang mengalami flebitis saja. Penelitian ini bertujuan untuk menganalisis hubungan pengetahuan dan sikap perawat dengan pelaksanaan patient safety. Penelititan ini menggunakan desain cross sectional. Sampel dalam penelitian ini adalah 20 orang perawat rawat inap di Puskesmas Bayan yang dipilih menggunakan teknik total sampling. Data dikumpulkan dengan menyebarkan kuesioner untuk variabel pengetahuan dan sikap perawat dan lembar observasi untuk variabel pelaksanaan patient safety. Analisa data menggunakan analisis statistik Spearmen Rho dengan nilai signifikan $\alpha<0,05$. Hasil penelitian menunjukkan ada hubungan antara pengetahuan perawat dengan pelaksanaan patient safety dengan nilai $\mathrm{p}=$ 0,000. Hasil penelitian juga menunjukkan ada hubungan sikap perawat dengan pelaksanaan patient safety dengan nilai $\mathrm{p}=0,007$. Dari hasil penelitian dapat disimpulkan bahwa pelaksanaan patient safety berhubungan dengan pengetahuan dan sikap perawat, semakin baik pengetahuan dan sikap perawat, akan semakin baik pelaksanaan patient safety.
\end{abstract}

Kata kunci: patient safety; pengetahuan; sikap; perawat

\section{KNOWLEDGE AND ATTITUDES OF NURSES ARE RELATED TO THE IMPLEMENTATION OF PATIENT SAFETY}

\begin{abstract}
Introduction: Patient safety is a variable to evaluate the quality of nursing service that influence the health care reduce the incidence of unexpected event in patients during the treatment. The implementation of patient safety in Puskesmas Bayan has been limited to the documentation of phlebitis cases among inpatient patients. This study aims to analyze the correlation between the knowledge and the attitudes of nurses and the implementation of patient safety. Method: This study uses cross sectional design. Samples were 20 nurses of Puskesmas Bayan, selected using total sampling technique. The data of nurses' knowledge and attitudes were collected using questionnaire and the data of the implementation of patient safety was collected using observation list. Data was analysed using spearmen Rho statistical
\end{abstract}


test with significance of $\alpha<0,05$. Result showed that there was a correlation between nurse knowledge and the implementation of patient safety $(\mathrm{p}=0.000)$. There was a correlation between nurses' attitude and the implementation of patient safety ( $p=0.007)$. It can be concluded that the implementation of patient safety is correlated to the knowledge and the attitude of nurses. The better knowledge and attitude of the nurses have, the higher quality of patient safety can be implemented.

Keywords: patient safety; knowledge; attitude; nurses

\section{PENDAHULUAN}

Patient safety merupakan suatu variabel untuk mengukur dan mengevaluasi kualitas pelayanan keperawatan yang berdampak terhadap pelayanan kesehatan. Program patient safety adalah usaha untuk menurunkan angka kejadian tidak diharapkan (KTD) pada pasien selama dalam perawatan.

Studi pendahuluan yang dilakukan pada tanggal 02 oktober 2014 di Puskesmas Bayan dan hasil observasi pada perawat didapatkan data bahwa jumlah pasien yang mengalami flebitis selama 3 bulan terakhir mengalami peningkatan. Pendokumentasian insiden patient safety hanya sebatas pada jumlah pasien yang mengalami flebitis, selain itu sebagian besar perawat tidak mencuci tangan sebelum kontak dengan pasien. Data yang diambil dari buku timbang terima pasien, pada bulan Juli menunjukkan bahwa dari 78 pasien yang dirawat inap, sebanyak 15 pasien terkena flebitis. Pada bulan Agustus didapatkan sejumlah 19 pasien mengalami flebitis dari total 92 pasien dan terjadi peningkatan jumlah pasien flebitis sebanyak 21 pasien dari 75 pasien yang rawat inap pada bulan September.

World Health Organization (2007) telah menetapkan hand hygiene yang efektif untuk diterapkan yakni salah satunya mencuci tangan pada saat sebelum dan sesudah kontak dengan pasien. Panitia Pengendalian infeksi Nosokomial RS Dr. Karyadi Semarang (2004) menetapkan mencuci tangan sebelum dan sesudah melakukan tindakan perawatan menggunakan sarung tangan, gaun pelindung, masker, dan kaca mata pelindung. Hal tersebut berarti bahwa sebelum perawat melakukan tindakan/kontak dengan pasien, perawat harus mencuci tangan sebelum dan sesudah memakai sarung tangan.

Notoatmodjo (2007) menyatakan bahwa subyek akan berperilaku baru sesuai dengan pengetahuan, kesadaran, dan sikapnya terhadap stimulus. Pernyataan tersebut dapat diartikan bahwa pelaksanaan patient safety oleh perawat dapat dipengaruhi oleh pengetahuan dan sikap. Green (1980) dalam Notoatmodjo (2003) menjelaskan bahwa perilaku seseorang 
atau masyarakat tentang kesehatan ditentukan oleh pengetahuan, sikap, kepercayaan dan tradisi sebagai faktor predisposisi disamping faktor pendukung seperti lingkungan fisik, prasarana dan faktor pendorong yaitu sikap dan perilaku petugas kesehatan atau petugas lainnya.

\section{METODE}

Penelititan ini menggunakan desain cross sectional. Sampel dalam penelitian ini adalah perawat rawat inap di Puskesmas Bayan dengan menggunakan teknik total sampling dan didapatkan responden sebanyak 20 orang. Variabel independen pada penelitian ini adalah Pengetahuan dan sikap perawat, sedangkan variabel independennya adalah pelaksanaan patient safety. Data dianalisis menggunakan analisis statistik Spearmen Rho dengan nilai signifikan $\alpha<0,05$.

Instrumen untuk mengukur pengetahuan perawat tentang patient safety menggunakan kuesioner yang sebelumnya telah digunakan oleh Mursyastuti (2010) dengan hasil uji validitas dengan tabel $r$ product moment dengan $n=30$ dan taraf signifikansi sebesar $95 \%$ diperoleh nilai $\mathrm{r}$-tabel $=0,361$, dari 20 butir pernyataan ternyata koefisien korelasi semua butir pernyataan dengan skordiatas 0,361 , sehingga semua butir pertanyaan dinyatakan valid.

Instrumen untuk mengukur sikap perawat yaitu dengan skala likert dan telah dilakukan uji validitas dengan $\mathrm{r}$ product moment. Hasil yang didapatkan seluruh item dinyatakan valid, dengan $n=10, r$ hitung $>$ dari $r$ tabel $(0,632)$. Uji reabilitas pada kuesioner sikap didapatkan nilai alpha croncbach 0,940 yang berarti kuesioner tersebut sangat reliabel. Variabel dependen diukur dengan menggunakan lembar observasi.

\section{HASIL}

Data demografi responden menunjukkan sebagian responden berusia 31-40 dan perawat di ruang rawat inap Puskesmas Bayan didominasi oleh perawat perempuan yakni sejumlah $65 \%$.

Tabel 1. Tabulasi Silang Analisis Hubungan Pengetahuan Perawat dengan Pelaksanaan Patient Safety

\begin{tabular}{ccccc}
\hline \multirow{2}{*}{ Pengetahuan } & \multicolumn{3}{c}{ Pelaksanaan patient safety } & \multirow{2}{*}{ Total } \\
\cline { 2 - 4 } & Tinggi & Sedang & Rendah & \\
\hline Baik & $11(55 \%)$ & $0(0 \%)$ & $0(0 \%)$ & $11(55 \%)$ \\
Cukup & $0(0 \%)$ & $8(40 \%)$ & $0(0 \%)$ & $8(40 \%)$ \\
Kurang & $1(5 \%)$ & $0(0 \%)$ & $0(0 \%)$ & $1(5 \%)$ \\
\hline Total & $12(60 \%)$ & $8(40 \%)$ & $0(0 \%)$ & $20(100 \%)$ \\
\hline
\end{tabular}




\section{Signifikansi $(\mathrm{p})=0,000$}

\section{Koefisien korelasi Spearmen Rho $(r)=0,806$}

Hasil analisis statistik uji korelasi Spearmen Rho dengan nilai $\mathrm{p}=0,000$ dan $r=0,806$

nilai signifikan $\mathrm{p}<0,05$. Hal tersebut berarti $\mathrm{H}_{1}$ diterima yaitu ada hubungan pengetahuan perawat dengan pelaksanaan patient safety. Correllation coefficient $r=0,806$ dapat di interpretasikan terdapat hubungan yang kuat antara kedua variabel dan arah hubungan yang positif

Tabel 2. Tabulasi Silang Analisis Hubungan Sikap Perawat dengan Pelaksanaan Patient Safety di Puskesmas Bayan Kabupaten Lombok Utara.

\begin{tabular}{ccccc}
\hline \multirow{2}{*}{ Sikap } & \multicolumn{3}{c}{ Pelaksanaan patient safety } & \multirow{2}{*}{ Total } \\
\cline { 2 - 4 } & Tinggi & Sedang & Rendah & \\
\hline Baik & $10(50 \%)$ & $2(10 \%)$ & $0(0 \%)$ & $12(60 \%)$ \\
Cukup & $2(10 \%)$ & $6(30 \%)$ & $0(0 \%)$ & $8(40 \%)$ \\
Kurang & $0(0 \%)$ & $0(0 \%)$ & $0(0 \%)$ & $0(0 \%)$ \\
\hline Total & $12(60 \%)$ & $8(40 \%)$ & $0(0 \%)$ & $20(100 \%)$ \\
\hline
\end{tabular}

Signifikansi $(\mathrm{p})=0,007$

Koefisien korelasi Spearmen Rho $(\mathrm{r})=0,583$

Hasil analisis statistik uji korelasi Spearmen Rho dengan nilai $\mathrm{p}=0,007$ dan $r=$ 0,583 . Nilai signifikan $\mathrm{p}=0,007$ artinya $\mathrm{p}<0,05$ hal tersebut berarti $\mathrm{H}_{1}$ diterima yaitu ada hubungan antara sikap perawat dengan pelaksanaan patient safety. Correlation Coefficient bernilai $r=0,583$ hal tersebut dapat diinterpretasikan bahwa terdapat arah hubungan yang postitif antara keduanya.

\section{PEMBAHASAN}

Hasil penelitian menunjukkan sebagian besar responden memiliki pengetahuan yang baik tentang patient safety. Pengetahuan merupakan hasil tahu dan ini terjadi setelah seseorang melakukan penginderaan terhadap suatu objek tertentu. Pengetahuan ini merupakan hal dominan yang sangat penting untuk terbentuknya tindakan seseorang (Notoadmojo 2007). Pengetahuan tentang patient safety dapat dikatakan sebagai unsur penting bagi setiap perawat dalam memberikan asuhan keperawatan yang aman kepada pasien.

Peneliti dalam hal ini juga menemukan sebagian kecil responden memiliki pengetahuan yang kurang tentang patient safety. Hal tersebut dapat disebabkan oleh kemampuan perawat tersebut untuk berfikir rasional, semakin terbuka terhadap pandangan orang lain dan informasi baru mengenai patient safety. Hal ini sesuai dengan teori Health 
Belief Model (HBM) yang menyatakan bahwa tingkat pengetahuan seseorang di pengaruhi oleh informasi dan lingkungan melalui proses pengalaman (Notoatmodjo, 2003).

Hasil penelitian menunjukkan sebagian besar responden memiliki sikap yang baik tentang pateint safety. Notoatmodjo (2007) mendefinisikan sikap sebagai reaksi yang masih tertutup dari seseorang terhadap suatu stimulus atau obyek. Sikap perawat merupakan respon terhadap materi patient safety yang telah di terima sebelumnya, dapat berupa respon mendukung ataupun tidak mendukung terhadap pelaksanaan patient safety. Materi patient safety yang diterima oleh perawat dapat bersumber dari institusi pendidikan sebelumnya, pengalaman kerja dan media massa. Sikap sebagai fungsi dari manusia seperti persepsi, motivasi, dan berfikir yang seperti itu menunjukkan hubungan-hubungan, bahwa sampai batas tertentu perilakunya dapat diramalkan.

Hasil penelitian menunjukkan sebagian besar responden memiliki tingkat pelaksanaan patient safety tinggi. Murdyastuti (2010) berpendapat bahwa salah satu hal yang dapat dilakukan oleh perawat untuk mencegah insiden keselamatan pasien (IKP) beserta dampaknya adalah dengan peningkatan kemampuan perawat untuk melaksanakan patient safety baik itu berupa pencegahan dini, deteksi risiko dan koreksi terhadap abnormalitas yang terjadi pada pasien. Perawat dalam hal ini dituntut untuk terus mengembangkan kemampuan dalam pemberian asuhan keperawatan secara aman. Penerapan patient safety tidak hanya akan bermanfaat untuk pasien, akan tetapi bermanfaat untuk perawat.

Hasil observasi peneliti didapatkan sebagian besar perawat tidak mencuci tangan sebelum kontak dengan pasien. Hal tersebut tidak sesuai dengan teori yang dikemukakan oleh WHO (2007) bahwa hand hygiene yang efektif untuk diterapkan yakni salah satunya mencuci tangan pada saat sebelum dan sesudah kontak dengan pasien. Panitia Pengendalian infeksi Nosokomial RS Dr. Karyadi Semarang (2004) menetapkan mencuci tangan sebelum dan sesudah melakukan tindakan perawatan menggunakan sarung tangan, gaun pelindung, masker, dan kaca mata pelindung. Hal tersebut berarti bahwa sebelum perawat melakukan tindakan/kontak dengan pasien, sangat penting bagi perawat mencuci tangan sebelum dan sesudah memakai sarung tangan. Kondisi tersebut dikarenakan hampir seluruh perawat belum mendapatkan informasi dan pelatihan yang lebih luas tentang pastient safety. Dalam hal ini Puskesmas belum melakukan standart keselamatan pasien ke-6 yakni mendidik staf tentang keselamatan pasien. Sehingga sebagian besar perawat tidak mengetahui pentingnya mencuci tangan sebelum kontak dengan pasien walaupun menggunakan sarung tangan.

Data dari hasil penelitian ini menunjukkan hampir seluruh responden memiliki sikap dalam kategori "baik" berusia 31-40 tahun. Hal tersebut sejalan dengan pernyataan Siagian 
(2005) bahwa usia berkaitan erat dengan tingkat kedewasaan atau maturitas, yang berarti bahwa semakin meningkat usia seseorang, akan semakin meningkat pula kedewasaannya atau kematangannya baik secara teknis, psikologis maupun spiritual, serta akan semakin mampu melaksanakan tugasnya. Usia yang semakin meningkat akan meningkatkan pula kemampuan seseorang dalam bersikap, mengambil keputusan, berfikir rasional, mengendalikan emosi, toleran dan semakin terbuka terhadap pandangan orang lain termasuk pula keputusannya untuk menerapkan patient safety

Hasil observasi menunjukkan sebagian besar responden memiliki tingkat pelaksanaan patient safety tinggi. Considine (2005) berpendapat bahwa salah satu hal yang dapat dilakukan oleh perawat untuk mencegah insiden keselamatan pasien (IKP) beserta dampaknya adalah dengan peningkatan kemampuan perawat untuk melaksanakan patient safety baik itu berupa pencegahan dini, deteksi risiko dan koreksi terhadap abnormalitas yang terjadi pada pasien. Perawat dalam hal ini dituntut untuk terus mengembangkan kemampuan dalam pemberian asuhan keperawatan secara aman. Penerapan patient safety tidak hanya akan bermanfaat untuk pasien, akan tetapi bermanfaat untuk perawat.

Berdasarkan hasil analisis statistik uji korelasi Spearmen Rho didapatkan ada hubungan antara pengetahuan dengan pelaksanaan patient safety. Hasil penelitian menunjukkan bahwa seluruh responden yang memiliki pengetahuan yang baik tentang patient safety memiliki tingkat pelaksanaan patient safety dalam kategori "tinggi". Notoatmodjo (2007) menyatakan bahwa pengetahuan merupakan hal dominan yang sangat penting untuk terbentuknya tindakan seseorang. Pengetahuan tentang patient safety yang diperoleh secara adekuat dapat menjadi dasar seorang perawat dalam menentukan tindakan yang aman kepada pasien. selain melalui pendidikan dan pelatihan, pengetahuan tentang patient safety juga dapat diperoleh dari jurnal-jurnal terbaru di internet ataupun media cetak.

Hasil analisis statistik uji korelasi Spearmen Rho didapatkan ada hubungan antara sikap dengan pelaksanaan patient safety. Sikap merupakan reaksi atau respon yang masih tertutup dari seseorang terhadap suatu stimulus atau obyek (Notoatmodjo 2003). Sikap dapat dikatakan sebagai kesiapan atau kesediaan untuk bertindak dan juga merupakan pelaksanaan motif tertentu. Hal ini sesuai dengan teori perilaku terencana (the theory of planned behavior), dimana perilaku atau niat untuk berperilaku dengan suatu cara tertentu, ditentukan oleh sikap seseorang terhadap perilaku, norma subjektif, dan anggapan kendali perilaku (Bensley \& Isher, 2009). Sikap tidak sama dengan perilaku, tetapi sikap selalu tercermin dari perilaku seseorang, semakin baik sikap seseorang maka pelaksanaan patient safetynya pun akan tinggi. 


\section{KESIMPULAN}

Sebagian besar perawat memiliki pengetahuan dan sikap yang baik tentanng patient safety. Pelaksanaan patient safety oleh perawat di Puskesmas Bayan Kabupaten Lombok Utara sebagian besar berada pada kategori tinggi. Terdapat hubungan yang signifikan antara pengetahuan dan perawat dengan pelaksanaan patient safety. Semakin baik pengetahuan dan sikap perawat tentang patient safety semakin tinggi pula dalam pelaksanaannya. Penelitian ini merekomendasikan upaya yang dapat dilakukan puskesmas untuk meningkatan pengetahuan dan sikap perawat tentang patient safety adalah dengan mengikut sertakan perawat dalam kegiatan seminar, presentasi karya ilmiah, loka karya, pelatihan dan studi lanjut ke jenjang yang lebih tinggi sehingga perawat-perawat di Puskesmas Bayan dapat menerapkan patient safety dengan optimal

\section{DAFTAR PUSTAKA}

Bensley, \& Isher. (2009). Metode Pendidikan Kesehatan Masyarakat (2 ed.). Jakarta: EGC.

Considine, J. (2005). The Role of Nurses in Preventing Adverse Events Related to Respiratory Dysfunction: Literature Review. Journal of advanced nursing, 49(6), 624-633. doi:10.1111/j.1365-2648.2004.03337.x

Murdyastuti, S. (2010). Pengaruh Persepsi Tentang Profesionalitas, Pengetahuan Patients Safety Dan Motivasi Perawat Terhadap Pelaksanaan Program Patients Safety Di Ruang Rawat Inap RSO Prof. Dr. R. Soeharso Surakarta. Universitas Sebelas Maret, Surakarta.

Notoatmodjo, S. (2003). Pendidikan dan Perilaku Kesehatan. Jakarta: Rineka Cipta. Notoatmodjo, S. (2007). Promosi Kesehatan dan Perilaku. Jakarta: PT Rineka Cipta.

Siagian, S. (2005). Manajemen Sumber Daya Manusia, Cetakan XII, PT. Bumi Aksara, Jakarta.

World Health Organization. (2007). WHO launches" nine patient safety solutions" to save lives and avoid harm [Press release]. Retrieved from http://scholar.google.co.id/scholar 